\title{
Monetizing Hijab: Analysis on State's National Interest on the Growing Hijab Fashion Trend in Indonesia
}

\author{
Witri Elvianti ${ }^{1}$, Nanda Amedina Putri ${ }^{2}$ \\ 1,2International Relations Study Program, President University \\ Email:w.elvianti@gmail.com
}

\begin{abstract}
Hijab and its practices grow consistently as an iconic fashion of Muslim women in Indonesia. This phenomenon yields scholarly commentaries pertaining to the motivation of hijab's massive production and Muslim women in veiling as well as the socioeconomic impact it carries with. However, the discussion on what sources of power underlie such a trend is still underrated. Therefore, this study aims at elucidating why now hijab receives greater support from the government under Joko Widodo's administration that illuminates massive production and consumption on hijab domestically. The analyst came to argue that hijab consumption and production has become Indonesia's national interest along with the mushrooming liberalization in its economy. Employing the qualitative research method to explain the source of power that makes hijab marketable in global and national market, the analyst also found that this trend is widely undermined by the implementation of neo-liberal economic policy that stresses the power of economic liberation of every individual while maintaining the state as the ultimate power of directing economic trajectory. Thus, the government of Indonesia seems to reconcile with the increasing domestic and global market demand on hijab. It is due to the state's interest in establishing Indonesia as a global hijab centre by 2020.
\end{abstract}

Keywords: hijab, fashion, national interest, neo-liberal economy.

\section{Abstrak}

Penggunaan hijab tumbuh secara signifikan sebagai gaya khas busana wanita Muslim di Indonesia. Sehingga mengundang banyak komentar ilmiah yang 
berkaitan dengan motivasi produksi besar-besaran hijab beserta dampak sosial ekonomi yang dibawanya. Namun, diskusi tentang kekuatan apa yang mendasari dan memotivasi pertumbuhan tersebut tidak banyak dibahas. Oleh karena itu, dengan mengacu pada tren mode hijab saat ini penelitian ini bertujuan untuk menjelaskan mengapa sekarang penggunaan dan produksi jilbab tumbuh secara konsisten dan menerima dukungan yang lebih besar dari rezim politik sekarang. Untuk mencapai tujuan ini, analis menggunakan metode penelitian kualitatif untuk menjelaskan tekanan yang mendorong tren penggunaan jilbab sehingga dapat diterima dan diproduksi secara nasional. Analis menemukan bahwa hijab dapat dipahami sebagai sarana penting untuk mencapai kepentingan nasional negara. Studi ini menemukan bahwa tren industri hijab mendapat pengaruh positif dari penerapan kebijakan ekonomi neo-liberal yang menekankan kekuatan kebebasan ekonomi setiap individu dengan tetap berkeyakinan bahwa negara sebagai kekuatan utama mengarahkan lintasan ekonomi. Hal ini dikarenakan tujuan utama yaitu membantu negara untuk mempercepat misi globalnya, yang menjadikan Indonesia sebagai pusat jilbab global pada tahun 2020.

Kata kunci: hijab, fesyen, kepentingan nasional, ekonomi neo-liberal.

\section{Introduction}

The practice of hijab and other form of Islamic fashion have been widely contested due to the symbolic meaning it carries with. Such a contestation remains present not only in Western societies where Muslim remains a minority group but also in an archipelagic country where Muslim remains the largest population, Indonesia. Muslim polity in Indonesia has experienced challenges in performing their Islamic identities. However, recent phenomenon evidently shows a contrasting background where hijab has transformed its meanings from symbolism of political identity to the marketable Muslim fashion icon. The latest view receives greater attention from scholars, politicians, and fashion designers as to alleviate the sacred values that hijab has previously brought to the public that becomes extremely apparent in Indonesia however remote the place is.

Some literatures have discussed the rising trend of hijab as an iconic Muslim fashion worldwide 
by focusing on the motivation of manufacturing and wearing hijab as well as the socioeconomic impacts it yields. On one hand, the literatures found that the rise of hijab can be seen from sociological unit of analysis. This perspective justifies that the trend of hijab represents the power of social media echoing the trend of searching new identity of Muslim women who reconstruct their beauty and piety “...regardless of the social interpretation attached to them" when wearing hijab (Listyani et al 2018).

On the other hand, a study conducted by Sari and Asad (2018) found that currently hijab is not contained in the larger scope of fashion industry; it is now part of Indonesia's fashion industry. This analysis managed to emphasize that the mushrooming production and use of hijab has consequently brought socioeconomic impacts to the business community. The quest for beauty in piety amongst Muslim women has become a new trend that promises pragmatist opportunities for generating incomes and greater market especially for those operating small medium enterprises. More interestingly, the demand on hijab does not only come from lowerincome family but also from the highly educated urban Muslim women and the elite government. The manifestation of government's support is shown in a series of fashion shows and public dialogues illuminating such a dramatic increase of hijab's practices and production.

Although these literatures have generated analytical discussion in hijab from both sociological and microeconomics point of views however the attention addressed to unveil the power that fuels the trend of the widening market of hijab remains insufficient. The existing literature that comprehends sociological narrative seems to reduce the importance of understanding greater power that give incentive to the group of individuals in maximizing any social media means available to highlight the global trend of Islamic beauty in hijab. In addition to this, assuming that financial consideration of market is high in the list of motivating factors of hijab practices and production then the question remains why should the government intervenes this market.

One can refer to a national fashion expo titled "Toward Indonesia as Hijab Fashion World Mecca" held in early October 2018 in Jakarta. With reference to this information, this study asked 
further research questions that, first, why now the government under Joko Widodo's administration which emerged from secular and nationalist yet anti-Islamist political front increasingly shows its support on hijab trend that gives incentive to the massive production and consumption on hijab domestically. Second, what source of power that makes hijab successfully attracts the government to generously reach the market on global and domestic level.

To substantiate those questions, the analyst employed qualitative research method and thus generated narrative based on its interpretation from secondary sources. The analyst viewed hijab as a strategic political and economic commodity. The state which becomes one of the most critical actors in international political economy holds substantial source of power to determine national political and economic trajectory of its nation. Therefore, the analyst treated the hijab trend as dependent variable and the state's interest as the first independent variable. As to comprehend its analysis, the analyst also question the power lies in the state's national interest and therefore it also treated the liberalization of global economy which also benefits the growing Muslim middle class as second independent variable.

In generating a solid foundation of its analysis, this study employed theory of national interest as well as neo liberal perspective in political economy. In this part, the analyst will elaborate the theoretical building of neo liberalism in global political economy and its correlation to the national interest theory. The neo liberal theorists of political economy highlight the presence of state in international market. Despite the effort to reducing state's intervention in ruling market as what classical liberal theorists have arguably defended, the neo liberal international political economy rather consolidates with the presence of states as to prevent market failure. To achieve this goal, the state must be able to prevent the presence of monopolies from any actors. The presence of monopoly represents the failure in maintaining market competitiveness and can hinder innovation in production, supply, and consumption. The state also has to provide protection toward individual freedom in economy. It then promotes the privatization of assets that previously operated under state's commando. Any asset in any form must be deregulated to make sure the "...free mobility of 
capital between sectors, regions, and countries" and all forms of barriers that potentially obscure "...that free movement... such as tariffs, punitive taxation arrangements, and other locational impediments" must also be eliminated "...except in those areas crucial to the national interest" (Harvey 2005).

On the other hand, the trajectory of state's foreign policy including its decision to actively participating in global collaboration in economy is determined by its national interest. National interest itself can be interpreted as the main reason of countries' preferences in participating in international political economy and building cooperation with other countries. According to liberalism, the birth of national interest theory is related to the contested discussion on the causes of war. To prevent war from perpetuation, the state's interest must be aligned with the pursuit of peace and harmonious relations among nations (Burchill 2005, 125). Neo liberalism also believes that rational principles of individuals can also be applied in the formulation of national interest and foreign policy of a state (Burchill 2005). Although neo-liberalism underlines competition among individuals, it rather highlights possibility of sharing interests and engaging in collaboration and cooperation at national and international level. This perception supposedly can result in greater benefits for every individual (Jackson, et al. 2003).

\section{The Failure of Suharto's Initiatives}

Prior to the massive evolution of economic globalization, it was a difficult task to trace evidences proving Indonesia's possession of high reputation in the realm of world fashion industry since the development of innovative fashion production and its materialization in Indonesia remained lacking. The government of Indonesia under Suharto's administration did not seriously take into account the optimization of garment sectors. In addition to this, it also contained the flourish of Islamic dress code from fashion industrialization. In this context, the stagnancy of Islamic dress code manufactures or the low appearance of hijab in Indonesia's domestic market were determined by the dominant perspective perceiving the practice of hijab as threatening national identity and reflecting religious extremism since the first place. The point of view the government utilized in figuring out the strategic role of hijab seemed to be similar to the politics 
of containment implemented by Dutch monopoly under the possession of VOC. Its occupation undermined the development of Indonesia's garment production and particularly blocked the practice of Islamic dress code.

Although garment manufacturers gave incentives to the innovation of fashion and market regulation in Southeast Asia, the production of hijab fashion in Indonesia was seen less importance more importantly when Suharto's authoritarian regime intensified its policy in garment sector in mid 1980s (TREDA 2009). In 1970s, for example, the government's inconsistency toward fashion sector was evident. In the beginning of these years, Suharto's administration claimed to renew national economic performance by undergoing liberalization with some limitation, however. Previously, the government concentrated in principles of exploiting row material resources and exploring agribusinesses sectors. Subsequently the government decided to switch its decision by focusing on export oriented policy especially that of coming from textile industry (Haq 1980). To realize such industrial transformation, starting in 1986 Suharto's administration performed "a series of liberalization measures..." that "... gave a massive stimulus to garment production" such as the creation of "...duty exemptions and incentive schemes" (Vickers 2012, 45; Thee 2005, 34159).

Unfortunately the trade liberalization by Suharto's administration did not totally take place since the regime adopted statist centric policy. Instead of becoming one of main fashion producers, it rather provided unskilled and cheap labors in textile manufactures. The strong control from the central government also created a space for monopolies and cronyism developed hugely that caused slow progress of innovation in fashion industry included Islamic fashion production. The lack of transparency and professionalism also negatively affected the sustainability of investment in this sector due to massive corruption and the imposition of export tax and tariff protection. Instead of experiencing positive endeavors, Islamic fashion industry fell into skepticism (James, 2002).

\section{Emerging Global Muslim Market And Hijab Fashion}

Assuming that Islamic fashion industry was skeptically perceived 
as a non-promising sector under Suharto's regime then why now it shows rather a contrary figure. Since the collapse of Suharto's political power that took effect in 1998, the flow of information nested in the wave of globalization happened to come across in Indonesia and transformed the expression of any religious symbols including Islamic fashion than ever before (Fachrurazi, 2017). Nevertheless, the invasion of cultural globalization and rapid information development cannot solely work to undermine the landscape of hijab fashion industry. In this part, the analyst comes to argue that the government's positive response to the growing trend of hijab fashion is due to the government's national interest toward hijab and its economy. The government reactively generates incentives to accelerate innovation on national hijab production to optimize the opportunities offered by the emerging power of Islamic global economy.

At global level, in many parts of Muslim majority countries, fashion, which then develops as part of popular culture and urban lifestyle, has become a critical engine in generating national income. The power of globalization has crafted Islamic economy, which comprises six main clusters which are halal food, Islamic finance, halal travel, modest fashion, halal media and recreation, as well as halal pharmaceuticals and cosmetics; which Islamic Finance and Halal Food becoming the weightiest indicator in global Islamic economy. Recently, the global economy is entering the phase of secular stagnation whereby the population keep ageing and there is a decrease in capital investment by business in both advanced and emerging market economies, this consequently will lower the living standard of future generation than previously expected as well as making the national debt burdens harder to reduce (IMF 2015).

Based on the data derived from State of the Global Islamic Economy Report year 2018/2019, in total the Islamic economy market size in 2017 is up to US\$ 2,107 billion. This number is made up of US\$2,438 billion from the Islamic Finance sector, US $\$ 1,303$ billion from the Halal Food sector, US\$ 270 billion from the Modest Fashion sector, US\$ 209 billion from Halal Media and Recreation, US\$ 177 billion from Halal Travel sector, US\$ 87 billion from Halal Pharmaceuticals, and US\$ 61 billion from Halal Cosmetics. This number is expected 
to reach US\$ 3,007 billion in 2023 , making global Islamic economy becoming stronger and stronger. On the other hand, Indonesia's Islamic economy also faces greater opportunity that importantly amends the liberalization of its national manufacturing sectors including textile industry and fashion trend. As globalization brings the entrance of capitalist power and free market system, it managed to give incentive to the materialization and fabricat ion of Islamic veiling. The expression of hijab practice becomes varied and thus strategically being turned as the commercialization of Islamic symbols to earn economic gains (Fealy 2008).

As a matter of fact, the Muslim consumers are estimated to comprise 1.8 billion of people which make the Muslim consumer market becoming a quarter of world's population, this number is accompanied with the global median age of Muslim consumers which is 24 ; age whereby t he purchasing and demand power is in the highest rate (Pew Research Forum 2011). Those large, young, and fast-growing global Muslim demographic goes together with the large and fast growing global Islamic economies; majorly the member states of The Organisation of Islamic Cooperation (OIC) had a GDP (PPP based) of \$7 trillion which represented $15 \%$ of the total global GDP of \$113 trillion in 2015. The average projected growth of the OIC market between 2015 until 2021 is expected to be $4.19 \%$ compared to the global growth of $3.6 \%$ even though the global economic growth is now in slow climate (IMF 2016). This is caused by the Islamic values or ethos that increasingly driving the lifestyle and business practice. Therefore, the OIC countries are focusing more and more into Islamic or halal market development through regulatory initiatives, economic incentives, and marketing program (Thomson Reuters 2016/2017, 14).

Making a third position as the biggest contributor to Global Islamic Economy, Islamic fashion is a unique case because it continues to grow despite the wider fashion industry is facing financial pressures due to the global recession. In recent years, modest fashion has gained momentum as it has moved solidly into the mainstream side of fashion industry. From retailers to high brand until catwalks, modest fashion is everywhere. The impact of the mainstreaming of modest fashion can be sum up into three main indicators, which are; the 
growth in modest fashion market size, an increasing competition due to the emerging of leading global apparel brands and retailers to modest fashion arena; and modest fashion product innovation.

The first impact is the market size. The clothing market for Muslims has become a part of the vast global clothing and accessories industry and value chain. Summarized from the State of Global Islamic Economy Report in the year of 2015/2016, 2016/2017, 2017/2018, and 2018/2019 developed and produced by Thomson Reuters in collaboration with Dinar Standard, hereby the data of the global Muslim market compared to the top global clothing market.

\begin{tabular}{|c|c|c|c|c|c|c|}
\hline & \multicolumn{5}{|c|}{$\begin{array}{c}\text { The Comparison of Global Muslim Market to Top } \\
\text { Global Clothing Market (in US\$, billion) }\end{array}$} \\
\cline { 2 - 7 } & $\begin{array}{c}\text { United } \\
\text { States }\end{array}$ & China & $\begin{array}{c}\text { Global } \\
\text { Muslim } \\
\text { Market }\end{array}$ & $\begin{array}{c}\text { United } \\
\text { Kingdom }\end{array}$ & German & India \\
\hline 2014 & $\$ 400$ & $\$ 310$ & $\$ 230$ & $\$ 107$ & $\$ 99$ & $\$ 96$ \\
\hline 2015 & $\$ 406$ & $\$ 344$ & $\$ 243$ & $\$ 114$ & $\$ 101$ & $\$ 99$ \\
\hline 2016 & $\$ 412$ & $\$ 357$ & $\$ 254$ & $\$ 116$ & $\$ 103$ & $\$ 109$ \\
\hline
\end{tabular}

From the table above, it can be shown that the Global Muslim Market is gradually growing throughout the years with recently it made up of almost $19 \%$ of global market in total. The Global Muslim Market is on the third position after United States and China in terms of the biggest market size globally. The growth of the Global Muslim Market is notably high too with 5\% growth in 2014 to 2015, and 4\% growth in 2015 to 2016; compared to the global market that only grows for $4 \%$ in 2014 to 2015 and 3\% in 2015 to 2016.
With the growth of global market, the global apparel brands and retailers turn its attention more in modest fashion. In 2015/16, the famous brand started to launch its Ramadhan collection such as Mango and Tommy Hilfiger and one of global brand which is Uniqlo has collaborated with Hana Tajima Collection to launch a casual modest wear line. In this year of modest fashion, the number of e-commerce players are also growing and expanding. The brands and e-commerce mostly focused on new product developments with 
"comfort" and "versatility" as key words.

Meanwhile, in the year of 2016/17, another global brand Marks and Spencer launched modest fashion product which is burkini collection because sport-wear is a high-growth segment in this era. Beside of sport wear, formal and luxury wear is also globally growing high. This year, several start-ups are showing signs of maturity by opening bricks and mortar stores and expanding product line, this achievement is also followed by the beginning of investor's interest in modest fashion segment because several notable capital investments relating to the Muslim fashion market have occurred.

There are not so much key developments of modest fashion between 2017/18 and 2018/2019 except that while it is used to only launch its Ramadhan collection, the global brands such as H\&M has launched its own modest fashion line named LTD. The largest United States retailers, Macy's also started to stock modest clothing label Verona. Another famous brand that actively promoting modesty is Dolce and Gabbana that started to collaborate with modest fashion influencer. This entrance of leading global apparel brands making the modest fashion industry becoming more and more competitive as there are also small and medium enterprises focusing on producing modest fashion product. Nowadays, the competition is between the raw materials producers, retailers, and designer or label as well as valuedadded manufacturers.

\section{Hijab Fashion And National Inte- rest}

Speaking of which hijab transformation, there are two critical phases marking the integration of hijab to the fashion realm which then stimulate the formulation of hijab as a lifestyle. The first phase emerged in 1990s where Hijab Revolution 1.0, took place. Within this period, Muslim polity experienced freedom of expressing their piety including the use of Islamic fashion. This was the foundation of Muslim fashion although hijab itself did not develop simultaneously yet. The next phase continued in the era 2010s where Hijab Revolution 2.0, emerged in the fashion world and inspired more Islamic fashion industries to increase innovation in technology and product quality in Indonesia. In the beginning 2000s, the fashion managed to maximize the liberalization of market economy through mass production. It then 
resulted in the capitalization of hijab and transformation of hijab from religious commodity to the expression of lifestyle. In this vein, innovation in hijab fashion as hijab becomes more fashionable, modern, and stylish combining Islamic virtue and modernity has stimulated competition among Islamic fashion designers to increase the quantity and quality of their hijab production to the international level. Hijab does not only address a classical Islamic teaching but also the acculturation of progressive Muslim and modernity. Consequently, it seems to be hard to draw a clear boundary differentiating motivation of Muslim women in veiling either for religious obedience or lifestyle follower (Puspitasari and Dolah 2018).

As to accelerate fashion economy, where Muslim market at global and domestic level becomes larger and promising, the government of Indonesia has significantly supported the establishment of hijab fashion as part of its national interest. Data from BPS in 2013 showed that there are as many as $1,107,955$ companies engaged in fashion sector. About $10 \%$ of them are large companies, $20 \%$ are medium enterprises and mostly $70 \%$ are small enterprises.
$30 \%$ out of 750,000 small clothing enterprises are hijab and Muslim fashion producers. The government remains conscious to making profit from this growing trend. To reach this end, the government must be able to keep domestic market steady to help hijab fashion industries grow consistently by providing mass consumers demand (Buera and Kaboski 2008). .

One thing that cannot be forgotten from the dynamics of Islamic fashion industry is the consumers itself, which Indonesia as the most Muslim populated country play a big role in it. The rising Muslim middle class comes to assume that they have adhered to "...the ethical use of wealth" (Hefner 2012). Year by year, Indonesia has been the top Muslim consumer clothing expenditure market, since it spent approximately US\$ 12.69 in 2014 and US\$ 13.28 billion in 2015 for Muslim clothing expenditure. This number grew into US\$ 13.5 billion in the year of 2016 and rocketed to US\$ 20 billion in the year of 2017 (Reuters 2017, 112). In order to promote hijab fashion domestically, Indonesia has held out several events such as fashion show, one of the notable fashion show is the Islamic Fashion Fair the largest annual fashion show. Besides, the 
government also encourages Muslim fashion enterprises to optimize the use of digital marketing to increase publicity and purchasing.

To demonstrate strong interest in hijab fashion, the government through its agency the Ministry of Trade in 2015 formally publicized the goal to make Indonesia a new centre of global Islamic fashion by 2020 . This interest seems to be equally important to the achievement of Indonesia's 2020 new industrial policy where the government targets to create Indonesia a new industrialized country. Indonesia and its large market possess powerful economic basis that can enhance its strategic position as the most influential key player in global modest fashion. Cooperating with Indonesia Islamic Fashion Consortium (IIFC), both the government and private sectors show their commitment to vision Indonesia as a world hijab fashion centre. It can be seen from the fact that more Indonesian designers also becoming the global modest fashion key players such as Dian Pelangi and Itang Yunasz. Retailers in Indonesia made up the majority of key players for modest fashion such as PT. Shafira Laras Persada, ELzatta, Hijup, Saqina, Matahari, and Moschaict. Particularly, the first Islamic e-commerce Hijup got achievement in investment by getting funding from 500 start-ups, Fenox venture capital and Skystar capital; it also showcased the work of 4 Indonesian designers at the international fashion showcase section of London Fashion Week, the first time of modest fashion's appearance in the event. Indonesia's Muslim market keep growing as it raised series a funding from 500 start-ups and other regional investors in recent years.

\section{Conclusion}

The discussion in this paper has a central point; analyzing the current growing trend on hijab fashion from state level of analysis. It has questioned why now the government of Indonesia consistently supported the expanding market of hijab. By way in contrast, hijab did not gain positive response during Suharto's regime; it was rather perceived a symbolic gesture of Islamic extremism which brought existential threat to national security. Recently, neither does the current regime show political affiliation to any Islamist political ideology. However, it demonstrates strong voice to the creation of hijab fashion as a new Islamic lifestyle. In elucidating this question, the analyst 
has employed national interest theory and neo-liberalism which then results in several key points.

Firstly, it seems to be valid arguing that the growing trend of hijab fashion is not always due to growing extremism. Instead, it significantly develops for government's consistent support by showing off its strong interest in making Indonesia a new global hijab fashion centre by 2020 . This goal is intended to accelerate the attainment of Indonesia's new industrial policy gaining a new status of Indonesia as a new developed and industrialized country by the same year. To reach this, the government must be able to comprehend its national economy by shifting its focus from raw material export to the manufacture sector. Thus, given that growing Muslim middle class as well as high consumers demand on Islamic fashion, the government perceives a great opportunity to sustain a strategic role for Indonesia in the global hijab fashion market. Therefore, the government seeks to establish steady market in domestic level to keep the industries grow increasingly by taking technology transfer and innovation development into account. Besides, the government also holds numbers of fashion shows, abroad and at home. In order to promote the most current and update hijab fashion the government also urges the use of digital marketing and social media. This is indeed coherent with the spirit of economic liberalization by which the government seeks to encourage individual creativity and innovation in producing high end hijab fashion.

Secondly, the government's interest to make Indonesia a global hijab fashion centre is also situated in global political economic context. Due to the increase of Muslim global consumerism on Islamic lifestyle including Islamic fashion, some states with large Muslim population decided to take the power of Muslim global market into account. Therefore, the government of Indonesia is currently dovetailing the expansion of its national hijab production to the global market level. To reach this goal, the government must show its strong commitment to support the growth of hijab and other Islamic garments.

\section{References}

Adas, E. B. (2006). The Making of Entrepreneurial Islam and the Islamic Spirit of Capitalism . Journal for Cultural Research, 113-137. 
Amer, S. (2014). What is Veiling. USA: The University of North Carolina Press.

Arrendt, H. (1958). The Human Condition. New York: Harcourt. Arrendt, H. (1951). The Origins of Totalitarianism. New York: Harcourt.

Bourdieu, P. (1996). Distinction. London: Routledge.

Dijk, V. (1997). Sarongs, jubbahs, and trousers. Appearance as a means of distinction and discrimination. In H. S. Nordholt, Outward Appearances. Dressing State and Society in Indonesia. Leiden: KIRLV Press.

Fachrurazi. (2017). Examining the Expression of Globalization and Commodification of Islam in Indonesia. International Journal of Scientific and Technology Research, 118-123.

Fealy, G. (2008). Consuming Islam: Commodified Religion and Aspirational Pietism in Contemporary Indonesia. In G. Fealy, \& S. White, Expressing Islam: Religious Life and Politics in Indonesia. Singapore: ISAS.

Geertz, C. (1960). The Religion of Java. New York: Free Press.

Gurbuz, M. E., \& Kucuksari, G. (2009). Between Sacred Codes and Secular Consumer Soci- ety: The Practice of Headscarf Adoption among American college girls. Journal of Muslim Minority Affairs , 387-400.

Haq, M. (1980). The Programming of Industrial Development and Regional Industrialization in the Republic of Indonesia. Vienna: United Nations Industrial Development Organization.

Harvey, D. (2005). A Brief History of Neo Liberalism. New York: Oxford University Press.

Hefner, R. W. (2012). Islam, Economic Globalization, and the Blended Ethics of Self. Bustan, The Middle East Book Review, 91-108.

Hoff, E. (2012). Political Economy and Its Components. Delhi : Orrange Apple.

Hooker, M. (2003). Indonesian Islam. Social Change Through Contemporary Fatawa. Honolulu: University of Hawai'i Press.

Hooker, M. (1986). The Law Texts of Muslim South-East Asia. In M. Hooker, Laws of South-East Asia, Vol.I The Premodern Texts (pp. 347-434). Singapore: Butterworths.

James, W. e. (2002). Indonesia's Textile and Apparel Industry: Meeting the Challenges of Changing International Trade Environ- 
ment. Kitakyushu: The International Centre tor the Study of East Asian Development.

Kuncoro, M. (2013). Indonesia's Textile and Its Products Industry: Recent Development and Challenges. The Business and Management Review , 126-139.

Lim, T. C. (2014). International Political Economy: An Introduction to Approaches, Regimes, and Issues. Saylor.

Nasr, V. (2010). The Rise of Islamic Capitalism: Why the New Muslim Middle Class is the Key to Defeating Extremism. New York: Free Press, Council of Foreign Relations Books.

Nef Saluz, C. (2007). Islamic Pop Culture in Indonesia. An anthropological vield study on veiling practices among students of Gadjah Mada University of Yogyakarta. Bern: University of Bern .

Puspitasari, Citra, Dolah, Jasni (2018), "The Analysis of Integration between Hijab Concept and Fashion in Indonesia", $A d-$ vances in Social Science, Education and Humanities Research. Atlantis Press: Vol. 207

Republic of Indonesia, Ministry of Trade, Warta Ekspor. Jakarta:
Ditjen PEN/WRT/31/IV/2015 April Edition.

Reuters, T. (2017). State of the Global Islamic Economy Report 2017/18. Retrieved from https://forms.thomsonreuters. com/ifgbusiness

Robertson, D. (2002). The Routledge Dictionary of Politics. New York : Europa Publication.

Sari, Rora, Asad, Nabila (2018), "Barrier in Design Innovation of Fashion Business: Evidence from Indonesian Moslem Fashion SME", Jurnal Dinamika Manejemen. 9 (1): 69-79.

Schumpeter, J. A. (2003). Capitalism, Socialism \& Democracy. London and New York: Routledge.

Smith-Hefner, N. J. (2007). Javanese Women and the Veil in PostSoeharto Indonesia. The Journal of Asian Studies, 389-420.

Tantowi, A. (2010). The Quest of Indonesian Muslim Identity: Debates on Veiling from the 1920s to 1940s. Journal of Indonesian Islam, 62-90.

Thee, K. W. (2005). Policies Affecting Indonesia's Industrial Technology Development. ASEAN Economic Bulletin , 341-59.

TREDA. (2009). kemendag. Retrieved January 3, 2019, from Min- 
istry of Trade Republic of Indonesia Web Site: http://www. kemendag.go.id/files/profil/ fashion.pdf

Van Dick. (1997). Sarongs, jubbahs, and trousers. Appearance as a means of distinction and discrimination. In H. S. Nordholt, Outward Appearances. Dressing State and Society in Indonesia. Leiden: KIRLV Press.
Vickers, A. (2012). Clothing Production in Indonesia: A Divided Industry. Institutions and Economies , 41-60.

Woodward, M. (1989). Islam in Java: Normative Piety and Mysticism in the Sultanate of Yogyakarta. Tueson : University of Arizona Press. 